\title{
The Effect of Deep Breathing Therapy on the Blood Pressure of Hypertension Patients in Health Centre
}

\author{
Rezkiyah Hoesny ${ }^{{ }^{*}}$, Zainal Alim ${ }^{1}$, Darmawati ${ }^{1}$ \\ 1) Department of Nursing, Kurnia Jaya Persada Palopo College of Health Sciences \\ rezkiyah89@gmail.com \\ DOI: http://doi.org/10.29080/jhsp.v3i3S.285
}

\section{Keywords}

Deep Breath

Therapy;

Blood Pressure;

Hypertension.

\begin{abstract}
Hypertension is an increase in persistent blood pressure which can be at risk for cardiovascular diseases. An uncontrolled increase in blood pressure can cause damage to the, heart and blood vessels. The purpose of this study is to analyze the effect of deep breathing therapy on blood pressure in hypertension patients in the work area of Wara Health Centre. The research design used Quasi Experiment, one group pre-test and post-test design, to 22 respondents selected by accidental sampling. Respondent's blood pressure was measured (pre-test), then breathing therapy was carried out for 15 minutes, then the respondent's blood pressure was measured (post-test). This intervention was carried out for three consecutive days for each respondent. The results indicated the average value of systolic blood pressure before deep breathing therapy get the probability value of 0.000 showing $0.000<0.05$ and the average value of diastolic blood pressure before deep breathing therapy get the probability value of 0.000 showing $0.000<0.05$. It can be concluded that there is an effect of deep breath therapy on blood pressure in hypertensive patients in the working area of Puskesmas Wara. It is recommended to apply breath therapy in the treatment of hypertensive patients, carry out training for health workers, cadres, and also families, so that this therapy can be carried out independently by patients at home.
\end{abstract}

\section{Introduction}

Hypertension is a silent killer that signs and symptoms resemble other diseases where the condition causes an increase in blood pressure which gives a continuous symptom to a target organ of the body resulting in more severe damage. Individuals with hypertension show low general well-being, experience more severe psychological distress, worse health status, physical symptoms, and functional disabilities and reduced time spent in social activities (1). Increased blood pressure is one of the risk factors for diseases such as myocardial infarction and stroke. Uncontrolled hypertension is also associated with high mortality rates, especially in middle and high income countries. It is estimated that around $80 \%$ of cases of hypertension occur mainly in developing countries in 2025, from a total of 639 million cases in 2000 . This number is expected to increase to 1.15 billion cases in 2025 (2). Hypertension, which is often considered a symptom, will reduce the of life.

Lifestyle factors such as poor diet, obesity, physical activity, and smoking are risk factors for the development of hypertension. As a result, management of hypertension must be begun by modifying these lifestyle factors. Pharmacological therapy is used as the main management for hypertension .However, medication adherence varies, side effects of drugs are common and may require regular monitoring, in some individuals, it may not be effective. Therefore, additional non-pharmacological interventions that reduce blood pressure can be combined with lifestyle modifications, one of which is the deep breathing technique. Non-pharmacological management of deep breath relaxation therapy to reduce blood pressure in hypertensive patients is chosen because deep breath relaxation therapy can be carried out independently. It is relatively easy to do than other non-pharmacological therapies. It does not require a long time for therapy and can reduce the adverse effects of pharmacological therapy for people with hypertension.

Complementary and alternative therapies are diverse groups of medical and health care systems, practices, and products that are not currently considered part of conventional medicine (3). Based on Government Regulation No. 103 of 2014 concerning Traditional Health Services (Yankestrad) stated that 
Complementary Health Services can be carried out by Nurses. The role of nurses in alternative and complementary therapies is as executor, educator, counseling, coordinator, and researcher (4). There have been many previous studies that have examined those who can help improve the quality of health for hypertensive patients as one of the reasons for nurses to independently intervene. Professional nurses have an important role in providing comfort to patients so that it will improve the quality of their health.

The purpose of this study was to analyze the effect of a breath on blood pressure in hypertensive patients in the working area of the Wara Public Health Center in Palopo City. The hypothesis of this study is there is an effect of deep breath therapy on blood pressure.

\section{Methods}

This study used an experimental method with a pre-experimental design: one group pre-test and post-test design. The population in this study were all hypertensive patients in the Puskesmas Wara Palopo City Work Area in June 2017, the number of samples were the subject refer to 22 people who were selected using Accidental Sampling techniques with the inclusion criteria for patients diagnosed with hypertension, aged 30-70 years, willing to become respondents, has no history of hypotension during the past 6 months and receive home visits. The exclusion criteria are getting alternative or complementary therapies, experiencing mental disorders, suffering from asthma, suffering from chronic kidney failure, elderly with blood pressure $>170 \mathrm{mmHg}$, and taking antihypertensive drugs during the of deep breath therapy. Data collection uses observation sheets to observe the administration a deep breath therapy interventions and write the results of blood pressure measurements before and after the intervention. Mercury sphymomanometer in mmHg was used to measure blood pressure before or after intervention. Previously, researchers explained the benefits of research, the possible risks and inconveniences caused and guaranteed anonymity and confidentiality. The data collection procedure was the respondent signed an informed consent, when intervening the position of semi fowler respondent. Blood pressure was measured before intervention. Then, the respondent's hands were placed on the stomach and chest. Encourage breathing slowly and deeply through the nose and inhale for \pm 3 seconds (maximum 5 seconds), feel. Hold breath for \pm 3 seconds (maximum 5 seconds). Gently exhale slowly through the mouth for 5 seconds. Encourage breathing with a normal rhythm 3 times. Performed for 15 minutes, and rest lightly every 5 times breathing.Then measure the patient's final blood pressure (post-test). This was done for 3 consecutive days on one respondent. Data were analyzed using SPSS version 20.0.

\section{Results}

An univariate analysis is used to describe the characteristics of each variable studied.

Table 1. Distribution of Systolic Blood Pressure Before Intervention (Pre-Test)

\begin{tabular}{ccc}
\hline Systolic $(\mathrm{mmHg})$ & Frequency & Percentage(\%) \\
\hline $130-159$ & 15 & 68,2 \\
$160-180$ & 7 & 31,8 \\
\hline Total & 22 & 100 \\
\hline
\end{tabular}

Table 2. Distribution of Systolic Blood Pressure Before Intervention (Pre-Test)

\begin{tabular}{ccc}
\hline Diastolic $(\mathrm{mmHg})$ & Frequency & Percentage(\%) \\
\hline$\leq 85-89$ & 13 & 59,1 \\
$90-99$ & 9 & 40,9 \\
\hline Total & 22 & 100 \\
\hline
\end{tabular}

Table 3. Distribution of Systolic Blood Pressure After Intervention (Post-Test)

\begin{tabular}{ccc}
\hline Systolic $(\mathrm{mmHg})$ & Frequency & Percentage $(\%)$ \\
\hline $130-159$ & 21 & 95,5 \\
$160-180$ & 1 & 4,5 \\
\hline Total & 22 & 100 \\
\hline
\end{tabular}

Table 4. Distribution of Systolic Blood Pressure After Intervention (Post-Test)

\begin{tabular}{ccc}
\hline Diastolic $(\mathrm{mmHg})$ & Frequency & Percentage $(\%)$ \\
\hline$\leq 85-89$ & 21 & 95,5 \\
$90-99$ & 1 & 4,5 \\
\hline Total & 22 & 100 \\
\hline
\end{tabular}

The table above shows the before and after the intervention. Table 1 shows that before the 
intervention was carried out, most of the respondents who had the blood pressure of $130-159 \mathrm{mmHg}, 15$ respondents (86.4\%) and respondents who had a systolic blood pressure of 160-180 $\mathrm{mmHg}$ were 7 respondents $(31.8 \%)$. Table 3 shows that after being given breath therapy in systolic blood pressure of respondents in the categories 130-159 $\mathrm{mmHg}$ increased to 21 respondents $(95.5 \%)$ and after being given intervention the systolic blood pressure of respondents in the $160-180 \mathrm{mmHg}$ category reduced to 1 respondent $(4,5 \%)$.

Table 2 shows that before interventio nwas carried out, most respondents who had diastolic blood pressure < 85-89 $\mathrm{mmHg}$ as many as 13 respondents (59.1\%), and respondents who had a diastolic blood pressure of $90-99 \mathrm{mmHg}$ as many as 9 respondents (40.9\%). Table 4 shows that after being given breath therapy in diastolic blood pressure respondents in the category $<85-89 \mathrm{mmHg}$ increased to 21 respondents $(95.5 \%)$ and after being given intervention the diastolic blood pressure of respondents in the $90-99 \mathrm{mmHg}$ category was reduced to 1 respondent $(4,5 \%)$.

Table 5. Effect of Deep Breath Therapy on Blood Pressure

\begin{tabular}{|c|c|c|c|c|c|c|c|c|}
\hline \multirow{2}{*}{$\begin{array}{c}\text { Blood } \\
\text { Pressure }\end{array}$} & \multicolumn{2}{|c|}{ Pre-test } & \multicolumn{2}{|c|}{ Post-test } & \multicolumn{2}{|c|}{ Change } & \multirow[t]{2}{*}{$\mathbf{t}$} & \multirow{2}{*}{$\begin{array}{c}\text { p- } \\
\text { value }\end{array}$} \\
\hline & Mean & $\begin{array}{c}\text { Std. } \\
\text { Deviation }\end{array}$ & Mean & $\begin{array}{c}\text { Std. } \\
\text { Deviation }\end{array}$ & Mean & $\begin{array}{c}\text { Std. } \\
\text { Deviation }\end{array}$ & & \\
\hline Sistolic & 155,77 & 9,807 & 141,50 & 10,423 & 14,273 & 5,006 & 13,372 & 0,000 \\
\hline Diastolic & 88,23 & 5,061 & 80,50 & 5,050 & 7,727 & 2,979 & 12,167 & 0,000 \\
\hline
\end{tabular}

Table 5 shows the average value of systolic blood pressure before being given deep breath therapy which is $155.77 \mathrm{mmHg}$ and the mean value after being given deep breath therapy is 141.50 . Furthermore, the average value of diastolic blood pressure before being given breath therapy in 88.23 and after giving breath therapy in an average value is 80.50 . The data were tested using the Kolmogorov-Smirnov normality test and obtained p-value of 0.710 more than 0.05 , it can be concluded that the data is normally distributed. From the results of the paired sample T-test statistical analysis, the value is $p=0,000<\alpha 0,05$, meaning that there is an effect of deep breath therapy on blood pressure in hypertensive patients in the working area of the health center in Palopo in 2017.

\section{Discussion}

The results showed that there was an effect of deep breath therapy on blood pressure in hypertensive patients in the working area of Wara Public Health Center, Palopo City. The average systolic blood pressure proves in hypertensive patients before the breath therapy was given $155.77 \mathrm{mmHg}$. Systolic blood pressure after being given deep breath therapy was $141.50 \mathrm{mmHg}$. The average value of diastolic blood pressure before given deep breath therapy was $88.23 \mathrm{mmHg}$ and the average value of diastolic blood pressure after being given deep breath therapy was $80.50 \mathrm{mmHg}$. There was a decrease in the blood pressure of the respondents after being given deep breath therapy, namely systolic blood pressure 14,273 $\mathrm{mmHg}$ and diastolic blood pressure 7,727 $\mathrm{mmHg}$.

Deep breathing is a conscious action to regulate breathing deeply by the cerebral cortex, while spontaneous breathing is carried out by the medulla oblongata. Deep breathingis done by reducing the frequency of breathing 16-19 times in one minute to 6-10 times in one minute. Deep breathing will stimulate the appearance of nitric oxide which will enter the lungs and even the center of the brain which functions to make people calmer so that high blood pressure will decrease. Nitric oxide is synthesized by the endothelial enzyme nitric oxide synthase (eNOS) of L-arginine. Increased activity of eNOS and the production of nitric oxide are influenced by factors that also increase intracellular calcium, and also include local mediators. The local mediators are bradykinin, histamine, and serotonin, as well as several neurotransmitters. Continuous production of nitric oxide will modulate vascular resistance, and it has been known that eNOS inhibition causes an increase in blood pressure (5).

Nitric oxide is a vasodilator that is important for regulating blood pressure and is released continuously from the arterial and arteriolar endothelium which will cause shear stress in endothelial cells due to blood viscosity against the vascular wall. The stress for medis being able to change the shape of endothelial cells in the direction of flow and cause an increase in the release of nitric oxide which then results in the blood vessels becoming relaxed, elastic, and dilated (5).

Relaxing blood vessels will widen so that blood circulation becomes smooth, the central venous pressure (CVP) decreases, and the heart's work becomes optimal. A decrease in CVP will be followed by a decrease in cardiac output and flat arterial pressure. Veins are larger in diameter than arteries which are equivalent and provide small resistance. Therefore, veins are also called capacitance vessels and work as reservoirs of blood volume (5). 
Cardiac output is the product of a single stroke and the frequency of the heart. Cardiac output is directly affected by 3 factors, namely filling volume or end-diastolic volume, ejection fraction, and heart frequency. Decreased blood volume and cardiac output can cause blood pressure to drop (5).

The results of this assessment are supported by previous research, namely Rita Dwi Hartanti et al. (2016), saying that there was a decrease in the blood pressure of respondents after deep breath relaxation therapy, namely systolic blood pressure of $18.46 \mathrm{mmHg}$ and diastolic blood pressure of $6.54 \mathrm{mmHg}$. Statistical analysis using paired sample T-test with a confidence level taken at 95\% with $\alpha$ 5\% (0.05), obtained a value of $\rho$ value of systolic blood pressure of 0.001 and $\rho$ value of diastolic blood pressure of 0.001 . This shows relaxation breathing therapy in effectively reducing blood pressure in hypertensive patients (6).

\section{Conclusion and Suggestion}

It can be concluded that there is a change in blood pressure before and after deep breath therapy. Paired sample T-test results showed that there was an effect of deep breath therapy on blood pressure in hypertensive patients in the working area of the Wara City Palopo health center in 2017. These interventions were easy to learn and apply to nurses, so that they could become independent interventions for pharmacological therapists for hypertensive patients. The application of breath therapy is recommended in conducting training for health center cadres and families, so that this therapy can be carried out independently by hypertensive patients and families at home. It is expected that in the next study, there will be respondents so that the results of the research can be used as guidelines for the management of hypertension, especially in the working area of the Wara City Palopo health center.

Several studies have been conducted to determine the effect of deep breath therapy on blood pressure in hypertensive patients. Most indicate the influence of deep breath therapy on blood pressure. Hypertensive patients who were respondents in this study did not use antihypertensive drugs to control their blood pressure during the research process, so that deep breath therapy was considered to have a large influence on changes in blood pressure. During the process of giving therapy, some respondents said they felt changes such as being more comfortable, relaxed, and easy to start sleeping.

\section{References}

1. Mei-Ling Y, Yu-Chun C, Yi-Ying H, Tso-Ying L. A Randomized Controlled Trial of Auricular Accupressure in Heart Rate Variability and Quality of life for Hypertension. ElSevier; 2015. 200-209 hlm.

2. Surantil. Penurunan Tekanan Darah Pada Pasien Hipertensi Di Puskesmas Andalas Kota Padang Tahun. 2016.

3. Black JM. Medical Surgical Nursing : Clinical Management for Positive Outcomes. USA: El Sevier; 2009.

4. Endeh ND. Alternative and Complementary Therapy in the Field of Nursing. Bogor: IN Media; 2015.

5. WardaniDW. Teknik Relaksasi Nafas Dalam Sebagai Terapi Tambahan Terhadap Penurunan Tekanan Darah Pada Pasien Hipertensi Tingkat 1. Skripsi.Jurusan Ilmu Kesehatan Masyarakat Fakultas Ilmu Keolahragaan. 2015.

6. Hartanti R, Wardana D, Fajar R. Breath Relaxation Theraphy in Lowering Blood Pressure in Hypertensive Patients. Jurnal Ilmiah Kesehatan (JIK). 2016;IX(1). 